\title{
Sexual Function in Women Who Experienced Domestic Violence
}

\author{
$1^{\text {st }}$ Lidia Hastuti \\ Lecturer, Community Nursing \\ Departement \\ STIK Muhammadiyah Pontianak \\ Pontianak, Indonesia \\ lidya_zain@yahoo.com \\ $4^{\text {th }}$ Wuriani \\ Lecturer, Medical Surgical Nursing \\ Departement \\ STIK Muhammadiyah Pontianak \\ Pontianak, Indonesia \\ $7^{\text {th }}$ Jaka Pradika \\ Lecturer, Medical Surgical Nursing \\ Departement \\ STIK Muhammadiyah Pontianak \\ Pontianak, Indonesia
}

\author{
$2^{\text {nd }}$ Lilis Lestari \\ Lecturer, Maternal and Pediatric \\ Nursing Departement \\ STIK Muhammadiyah Pontianak \\ Pontianak, Indonesia
}

$5^{\text {th }}$ Tisa Gusmiah

Lecturer, Medical Surgical Nursing

Departement

STIK Muhammadiyah Pontianak

Pontianak, Indonesia

$8^{\text {th }}$ Yanieta Arbiastutie

Lecturer, Forestry Faculty of

Universitas Tanjung Pura Pontianak

Pontianak, Indonesia

\author{
$3^{\text {rd }}$ Annisa Rahmawati \\ Lecturer, Medical Surgical Nursing \\ Departement \\ STIK Muhammadiyah Pontianak \\ Pontianak, Indonesia
}

\author{
$6^{\text {th }}$ Ridha Mardian \\ Lecturer, Medical Surgical Nursing \\ Departement \\ STIK Muhammadiyah Pontianak \\ Pontianak, Indonesia
}

\begin{abstract}
Violence against women by partners is a serious problem of public health which contributes to injuries whether as short-term or long-term health consequences. Based on the annual records of the women's national commission in 2017 , there were 259,150 cases of violence against women that being reported during 2016. Domestic violence occupy as the most cases being reported position for 903 cases $(88 \%)$ out of the total 1,022 cases being reported. Violence which occurs in the family might cause major problems in women's reproductive health, especially sexual function. Research's reports showedthat $20 \%-30 \%$ of women experienced sexual dysfunction such as not fervid to having sex, difficulty in lubricating and orgasm, as we know that sexuality is an important things in family life. This study was aimed to determine the prevalence and the types of violence, the prevalence of sexual dysfunction and the effects of domestic violence on female sexual function. Quantitative study with a cross-sectional design. Data collection techniques using multistage sampling with a sample size of 330 respondents in 10 districts. Quantitative analysis used chi-square. Univariate dan bivariat analysis found a prevalence of domestic violence of $11.2 \%$ with a prevalence of emotional violence of $10.9 \%$, verbal abuse of $7 \%$, the physical violence of $8.2 \%$ and sexual violence of $5.8 \%$. The prevalence of sexual dysfunction is $37.6 \%$. There is an influence between violence with female sexual function with $p=0.01(p<0.05)$ with $O R=6.95(95 \%$ CI 2.25-21.45). Women who experienced domestic violence are more likely to experience sexual dysfunction by 6.95 times compared to those who do not experience domestic violence. The study recommended the importance for further research related to the search of sexual function problems help and treatment at women who experienced domestic violence. Domestic violence affects the sexual function of women.
\end{abstract}

Keywords-Sexual function, women, domestic violence

\section{INTRODUCTION}

Serious actions done by the government in handling cases of domestic violence in Indonesia have been going on for a long time with the issuance of law number 23 of 2004 concerning the abolishment of domestic violence. The law is a guarantee by the government in taking steps to prevent domestic violence, sentence the perpetrators of violence and protect victims. Domestic violence in question is any act aimed at women that can cause physical, psychological, social and/or neglect of the household/family. Violence also includes threatening, coercing, and /or deprivation of liberty and acts against the law in the household ${ }^{(1)}$. All people are at risk of becoming perpetrators or victims of domestic violence, but according to annual records of the 2017 women's national commission 259,150 cases of violence against women were reported in 2016. Domestic violence occupies the position of the most reported cases as many as 903 cases $(88 \%)$ of a total of 1,022 cases were admitted (2). Violence against women done by partners is a serious problem and has consequences both short-term and longterm health problems ${ }^{(3)}$. Risk factors for domestic violence are related to age, family type, precarious work, income gaps and attitudes towards sex ${ }^{(4)}$. Besides the personality factor of the perpetrator, acting aggressively in dealing with situations that cause frustration such as prolonged economic difficulties, husband infidelity ${ }^{(5)}$ Women at risk as victims of violence are those who have partners who misuse alcohol, use drugs, unemployment, low education, or partner infidelity (6). In developing countries, domestic violence is related to socioeconomic status, education, demographics, age, number of children and the status of women's autonomy in the family ${ }^{(7)}$. 
The annual record of the women's national commission in 2017 was reported as many as 259,150 cases of violence against women during 2016. In the realm of households, physical violence was $42 \%$ (4,281 cases), sexual violence $34 \%$ (3,495 cases), psychological violence $14 \%$ (1,451 cases) and economic violence $10 \%$ $(978 \text { cases })^{(2)}$. Based on data on cases of violence handled by the West Kalimantan Regional Police, there were an increase of 456 cases in 2016, with 143 cases of domestic violence $^{(8)}$.

In addition to impacting on physical, mental conditions, self-esteem disorders, helplessness, depression and leaving deep trauma ${ }^{(9)}$, violence will also adversely affect a woman's reproductive health, especially on her sexual life in the family ${ }^{(10)}$. Women who experience domestic violence are at risk of experiencing sexual dysfunction ${ }^{(11)}$, while we know that sexuality is part of the quality of human life. The study reported, $20 \%$ $-30 \%$ of women complained of experiencing sexual dysfunction such as not interested in sex, difficulty lubricating, and difficulty achieving orgasm ${ }^{(12)}$. Less harmonious interpersonal relationships in women who experience violence, can inhibit a person's sexual activities and functions. A woman's psychological condition such as anxiety and feelings of fear of sex will affect her sexual function ${ }^{(13)}$. The study aims to determine the prevalence and type of violence, the prevalence of sexual dysfunction and the relationship between domestic violence and female sexual function.

\section{METHOD}

This study was a quantitative research with cross sectional study design. The method of taking samples was by using multi stage sampling. Samples were from 10 public health center from 2 districts using cluster sampling, with a total sample of 330 respondents. The research inclusion criterion in the study was that they were willing to take part in the study, women aged 17-45 years with married status and did not have hypertension, heart disease and diabetes mellitus. Instruments of violence using instruments from previous studies (11), while instruments of sexual function using FSFI (14). Researchers get ethical clearence number 155/II.I.AU/KET.ETIK/V/ 2019.
The study was conducted by maintaining the ethical principles of benefit, justice, and informed consent ${ }^{(13)}$. Informed consent and the signing of a consent letter of willingness as a respondent by women of childbearing age. Bivariate analysis using chi square.

\section{RESULT}

The results showed the data about the characteristics of the study subjects, the prevalence of women who experienced domestic violence, sexual function and their relationship.

A. Univariate analysis

1) Characteristics of respondents

Description of the characteristics of the majority of research respondents aged between 20-45 years (96.4\%), $34.24 \%$ had a high school education degree (SMA). Most of head of family work in private sector $(69.4 \%)$, the majority of respondents earn more than the minimum wage $(91,31 \%)$. The percentage of physical violence was $8.2 \%$ (27 respondents), psychological violence was $10.9 \%$ (36 respondents), verbal violence was $7 \% \quad$ (23 respondents), and sexual violence was $5.8 \%$ (19 respondents).

2) Prevalence of domestic violence and sexual function

The prevalence of domestic violence and sexual function in women can be seen in Table 1 below:

TABLE 1. PREVALENCE OF DOMESTIC VIOLENCE AND SEXUAL FUNCTION

\begin{tabular}{|l|c|c|}
\hline VARIABEL & $\mathrm{N}=330$ \\
\cline { 2 - 3 } & $\mathrm{F}$ & $\%$ \\
\hline Domestic violence & & \\
Yes & 37 & 11,2 \\
No & 293 & 88,8 \\
\hline Sexual function & & \\
Dysfunction & 124 & 37,6 \\
Normal & 206 & 62,4 \\
\hline
\end{tabular}

Source: Primary Data 2019

The results found that the prevalence of women who experienced domestic violence was $11.2 \% \quad$ (37 respondents), and the prevalence of sexual dysfunction was $37.6 \%$ (124 respondents)

B. Bivariate analysis

Bivariate analysis aims to analyze the relationship between domestic violence and sexual function, as seen in Tables 2 and 3 .

TABLE 2. SEXUAL FUNCTION IN WOMEN WHO EXPERIENCE VIOLENCE

\begin{tabular}{|c|c|c|c|c|c|c|c|c|c|c|}
\hline \multirow[t]{3}{*}{ Variabel } & \multicolumn{4}{|c|}{$\mathrm{n}=330$} & \multirow{2}{*}{\multicolumn{2}{|c|}{ Total }} & \multirow[t]{3}{*}{$\chi$} & \multirow[t]{3}{*}{$\mathrm{P}$} & \multirow[t]{3}{*}{ OR } & \multirow[t]{3}{*}{$95 \% \mathrm{CI}$} \\
\hline & \multicolumn{2}{|c|}{ Dysfunction } & \multicolumn{2}{|c|}{ Normal } & & & & & & \\
\hline & $\mathrm{f}$ & $\%$ & $f$ & $\%$ & $\mathrm{f}$ & $\%$ & & & & \\
\hline \multicolumn{11}{|l|}{ Violence } \\
\hline Yes & 23 & 62,2 & 4 & 37,8 & 7 & 11,22 & 10,73 & $0.002 * *$ & 3,12 & $1,54-6,33$ \\
\hline No & 101 & 34,5 & 192 & 65,5 & 293 & 88,78 & & & 1 & \\
\hline
\end{tabular}

Statistical test results show that there is a significant relationship between violence with female sexual function with a value of $\mathrm{p}=0.002(\mathrm{p}<0.05)$. Estimation test results found that women who experience violence are at risk for experiencing sexual dysfunction by 3.12 times compared to those who do not experience violence $(\mathrm{OR}=3.12,95 \%$ $\mathrm{CI}=1.54-6.33)$. 
TABLE 3. SEXUAL FUNCTION IN WOMEN BASED ON THE TYPE OF VIOLENCE EXPERIENCED

\begin{tabular}{|c|c|c|c|c|c|c|c|c|c|c|c|}
\hline \multirow[t]{3}{*}{ Variabel } & \multicolumn{4}{|c|}{$\mathrm{n}=330$} & \multirow{2}{*}{\multicolumn{2}{|c|}{ Total }} & \multirow[t]{3}{*}{$\chi$} & \multirow{3}{*}{\multicolumn{2}{|c|}{$\mathrm{P}$}} & \multirow[t]{3}{*}{ OR } & \multirow[t]{3}{*}{$95 \% \mathrm{CI}$} \\
\hline & \multicolumn{2}{|c|}{ Dysfunction } & \multicolumn{2}{|c|}{ Normal } & & & & & & & \\
\hline & $\mathrm{f}$ & $\%$ & $\mathrm{f}$ & $\%$ & $\mathrm{f}$ & $\%$ & & & & & \\
\hline \multicolumn{12}{|c|}{ Physical abuse } \\
\hline Yes & 17 & 63 & 10 & 37 & 27 & 8,2 & \multirow[t]{2}{*}{8,08} & \multirow{2}{*}{\multicolumn{2}{|c|}{$0.008 * *$}} & 3,11 & \multirow[t]{2}{*}{$1,37-7,04$} \\
\hline No & 107 & 35,3 & 196 & 64,7 & 303 & 91,8 & & & & 1 & \\
\hline \multicolumn{12}{|c|}{ Psychic violence } \\
\hline Yes & 20 & 55,6 & 16 & 44,4 & 36 & 10,9 & \multirow[t]{2}{*}{5,56} & \multirow{2}{*}{\multicolumn{2}{|c|}{$0,018^{*}$}} & 2,28 & \multirow[t]{2}{*}{$1,13-4,59$} \\
\hline No & 104 & 35,4 & 190 & 63,6 & 294 & 89,1 & & & & 1 & \\
\hline \multicolumn{12}{|c|}{ Verbal violence } \\
\hline Yes & 13 & 56,5 & 10 & 43,5 & 23 & 6,97 & \multirow[t]{2}{*}{3,78} & \multirow{2}{*}{\multicolumn{2}{|c|}{$0,04 *$}} & 2,29 & \multirow[t]{2}{*}{$0,97-5,40$} \\
\hline No & 111 & 36,2 & 196 & 63,8 & 307 & 93,03 & & & & 1 & \\
\hline \multicolumn{12}{|c|}{ Sexual violence } \\
\hline Yes & 15 & 78,9 & 4 & 11,9 & & 19 & 5,75 & 14,7 & $0,00 * *$ & 6,95 & $2,25-21,45$ \\
\hline No & 109 & 35 & 202 & 65 & & 311 & 94,25 & & & 1 & \\
\hline
\end{tabular}

Statistical test results show that there is a significant relationship between physical violence with a value of $p$ $=0.008(\mathrm{p}<0.05)$, psychological with a value of $\mathrm{p}=0.018$ $(\mathrm{p}<0.05)$, verbal with a value of $\mathrm{p}=0.04(\mathrm{p}<0,05)$ and sexual with a value of $\mathrm{p}=0.008(\mathrm{p}<0.00)$ with female sexual function. Estimation test results found that women who experience physical violence are at risk of experiencing sexual dysfunction by 3.1 times compared to those who do not experience physical violence $(\mathrm{OR}=3.11$, 95\% CI $=1.37-7.04)$, who experience psychological violence are the risk of experiencing sexual dysfunction by 2.28 times compared to those who did not experience physical violence $(\mathrm{OR}=2.28,95 \% \mathrm{CI}=1.13-4.59)$, those experiencing verbal violence are at risk of experiencing sexual dysfunction by 2.29 times compared to those who did not experience physical violence $(\mathrm{OR}=2.29,95 \% \mathrm{CI}$ $=0.97-5.4$ ), while those who experienced verbal sexual violence to experience sexual dysfunction by 6.95 times compared to those who did not experience physical violence $(\mathrm{OR}=6.95,95 \% \mathrm{CI}=2.25-21.45)$

\section{DISCUSSION}

This study found differences in the prevalence of domestic violence with previous studies, the prevalence of domestic violence in this study was $11.2 \%$, in line with the study in several countries ranging from $15 \%-71 \%{ }^{15}$. But the results of this study found that the rate of violence was lower than the results of previous studies of $17.35 \%$ (11). The socialization of the law on the elimination of domestic violence is thought to have a positive effect on the reduction in cases of violence that occurred in Indonesia, although there are still reports of domestic violence cases in the police station. The existence of a legal Indonesian women's legal aid foundation (YLBHPIK) is a forum for women to fight for their rights and assist women in dealing with various problems that require legal assistance. The results showed that the prevalence of sexual dysfunction was $37.57 \%$. The results of this study are in line with the results of previous studies which found that sexual dysfunction was in the range of $20-30 \%{ }^{(12)}$. But it differs from previous studies which found that sexual dysfunction in women who experienced violence amounted to $14.87 \%{ }^{(11)}$. This data difference can be caused by differences in research locations and the size of the study sample. Now, the tendency of women are to be more open to sexual problems and begin to understand the importance of sexuality problems in the family.

The results found that there was a relationship between domestic violence and sexual function in women who experienced domestic violence. The results of this study are in line with the results of research conducted ${ }^{(11)}$. Domestic violence is related to sexual function in women. Women who experience violence are at risk for experiencing dysfunction as compared to women who do not experience violence.

The limitation of this study is that the location of the study is in basic health services/public health center, so that there were only a few can represent women with high socioeconomic status. Data shows that those who come to the public health center tend to have middle to lower socioeconomic status. This research also needs to study other factors related to female sexual function in addition to the problem of violence and the search for health problems as a result of violence experienced by women.

\section{CONCLUSIONS AND SUGGESTIONS}

This study found that the prevalence of domestic violence was $11.2 \%$ and sexual dysfunction in women was $37.6 \%$. There is a relationship between domestic violence and female sexual dysfunction with a value of $p$ $=0.00(\mathrm{p}<0.05)$. Women who experienced domestic violence were at risk of experiencing sexual dysfunction by 3.12 times compared to those without violence $(\mathrm{OR}=$ $3.12,95 \% \mathrm{CI}=1.54-6.33$ ). The results of the study proved a relationship between violence in the household with sexual dysfunction. So it is necessary to conduct early detection of sexual problems in women and take immediate treatment to reduce the risk of sexual dysfunction that adds to health problems due to acts of violence.

\section{ACKNOWLEDGMENTS}

The researchers would like to thanks the Pontianak City Government, Kubu Raya Regency, Public health centre, Women's Empowerment Office, the Police, in both of the data collection areas, Pontianak City YLBH PIK and Research Funders from the Ministry of Research, Technology and Higher Education, Research Institutions of STIK Muhammadiyah Pontianak. 


\section{REFERENCES}

[1] http://www.bphn.go.id/data/documents/04uu023.pdf

[2] https://www.komnasperempuan.go.id/file/pdf_file/2017\%20Siar an\%20Pers/Lembar\%20Fakta\%20Catahu\%202017.pdf)

[3] Ramsay, J., Richardson, J., Carter, Y.H., Davidson, L.L., Feder,G 2002. Should health professionals screen women for domestic violence? Systematic review BMJ 2002; 325 doi: https://doi.org/10.1136/bmj.325.7359.314

[4] Andersson, N., Foster,A.H., Mitchell, S, Scheepers, E, Goldstein,S. 2007. Risk Factor for domestic phisicalviolence:National cross-sectional household survey in south African Countries, BMC Women's Health, 7:11 doi:10.1186/1472-6874-7-11

[5] Kereh, O.A., Anis, F.H., 2017. Aspek hukum kekerasan dalam rumah tangga berdasarkan UU. No 23 tahun 2004. Lex Et Societatis Vol. V/No. 9

[6] Demetrios, N., Kyriacou, M.D., Deirdre, A., Ellen, T., Susan, S., Toni, T., Judith, A.L., et al. 1999. Risk factors for injury to women from domestic violence. The New England Journal of Medicine, Vol. 341. No. 25. p1892-1898

[7] Koenig, M.A., Lutalo, T., Zhao, F., Nalugoda, F., Mangen, F.W.,Kiwanuka, N., Wagman, J.,Serwadda, D., Wawer, M., \&Gray,R (2002). Domestic Violence in Rural Uganda: Evidece from a community-base study. Bulletin of the World Health Organization.,81 (1)

[8] Melano, R., K.,S. 2017. Selama tahun 2016, Polda Kalbar tangani 456 kasus kerasan perempuan dan anak. (http://pontianak.tribunnews.com/2017/05/16/selama-2016polda-kalbar-tangani-456-kasus-kekerasan-perempuan-dananak)

[9] Sutrisminah. E. 2012. Dampak Kekerasan Pada Istri Dalam Rumah Tangga Terhadap Kesehatan Reproduksi. Majalah ilmiah Sultan Agung. Vol 50. No.127. ISSN: 2252-729X

[10] Golding, A.M.B. 2002. Domestic Violence. Journal of the Royal Society of Medicine, vol:95:30:3007-3008

[11] Hastuti, L., Suriadi, Kardiatun, T., Ligita, T. 2011. The Relationship between Domestic Violence and Women's Sexual Function in the City of Pontianak. International Journal of Public Health Research Special Issue 2011, pp (139-145)

[12] Nicolosi, A., Laumann, E.Q., Glasser, Moreira, Paik, A., Gingell, C., 2005. Sexual Behavior and sexual dysfunction after age 40: The Global Study of sexual attitudes and behaviors. Elseiver Journal, Nov;64(5): 991-7.

[13] Smyth, A.M.D., 2002, Sexual problem overview. (http://www.health.allrefer.com/special topic.html)

[14] Rosen,R., Brown,C., Heiman,J., Leiblum,S., Meston,C., Shabsigh,R., Ferguson,D., D'Agostino,R., 2000, The Female Sexual Function Index (FSFI): A Multidimensional Self-Report Instrument for theAssessment of Female Sexual Function, Journal of Sex \& MaritalTherapy, 26:191-208.

[15] Garcia,C.G., Jansen,H.A.F.M., Ellsberg,M. Heise,L., Watts,C.H. 2005. Prevalence of intimate partner violence: findings from the WHO multi-country study on mowen's health and domestic violence. WHO Press, World Health Organization, 20 Avenue Appia, 1211 Geneva 27, Switzerland ISBN 924159358 X 